\title{
Accounting Information System Web Based in Middle School Muhammadiyah 3 Bandung
}

\author{
Endang Amalia \\ Information System, Widyatama University, Bandung, \\ 40125, Indonesia \\ endang.amalia@widyatama.ac.id
}

\author{
Dior B. Gunawan* \\ Information System, Widyatama University, Bandung, \\ 40125, Indonesia \\ diorbagja12@gmail.com \\ *Corresponding author
}

\begin{abstract}
This study aims to help solve accounting problems in the Muhammadiyah 3 junior high school where the research was conducted. The background of writing this report is because there are some problems that exist around accounting management including the work of financial employees who are still ineffective and inefficient, making reports that require an iterative process and employee service to parents of students. Research data collection through the process of library research and the process of interviews with financial employees. The research method used is the action research and the method of development is the Unified Software Development Process while the system modeling using the Unified Modeling Language is expected to maximize the desired results. Research carried out includes making a web-based financial information system in Muhammadiyah 3 junior high school including several factors, namely data management systems ranging from employee data, students, student finance, income, expenses and there is also making financial reports using a code igniter framework. It is hoped that the development of webbased information systems can overcome the existing accounting problems.
\end{abstract}

Keywords-Information systems, accounting, action research, unified software development process, unified model language, code igniter

\section{INTRODUCTION}

The development of technology in today's very fast making an information a vital tool in an organization. Processing a good information system can be a factor for the organization to develop, not only internal to the organization but also information processing can also be applied to consumers of an organization. Which makes processing a good information system can have a positive impact on an organization both from external and internal.

Accounting within the school environment is an important part of the on-going activities in the school environment. Where the Accounting section becomes a vital part that must record all income and expenses that occur in the school environment. Research is very important in accounting because it involves accuracy in writing numbers in the income and expense reports (FKIP Universitas Riau, 2015).

As an officer in the Accounting section it is required to have good research to support the smoothness of the Accounting department. However, in the school environment the duty of an Accounting section employee is not only to write expense and income reports but also to serve parents of students who come to inquire about their children's financial problems.

Services for parents of students can be very fatal because they can show the professionalism of the school in terms of service to the students so that the value of the school can also increase. The services provided are not just a matter of accuracy but also speed in processing the data so that the service can run quickly.

In working on the Accounting department which is now still using manual methods where employees write everything from the beginning this can lead to the potential for greater human error with the presence of accounting technology is expected to be at risk of fewer human errors. Not only that but with this Accounting technology can also make employee services to parents of students can run well. Using information technology is expected to make the work of accounting officers effective and efficient. Therefore,

\section{LITERATURE REVIEW}

Many previous studies that apply accounting information systems in the institutions under study by using computerization as a way out for the problems faced. In 2011 Khoirun conducted research in MAN 2 starch which applied VB-based applications as a way out that was able to overcome existing problems (Nasihin, 2011), basically similar research is also carried out not only around the scope of the school but also on the scope of the government and also the company. In the scope of 2014 the government used java based applications with problems in managing financial data in the village of Ngadirejan (Rusmayanti, 2014) while for companies there are Anisa and Marlina in 2018 using the zahir accounting application at PT. Gemilang Sukses Abadi Selaras (Yustia, 2018) as a way out of the problems that exist in the company. In working on an application there is a method in floating the system which will facilitate the 
assembly of applications in 2015 Indrawan and his colleagues use the waterfall method as a method of system development (Purnomo, et.al, 2015). The development phase requires a data analysis model that will be needed when modeling a system so that it can be easily read when building applications, Agus in 2013 used ERD as a model (Rochim, et.al, 2013) to describe the relationship between the system to be made.

With various kinds of research that have been carried out researchers decided to use action research as a methodology for writing scientific papers and then using the USDP method as a method of software development and UMl (Widodo, et. Al, 2011) as a model of the system's designed description.

\section{RESEARCH METHODS}

The research method that the authors apply is action research. Action research is a form of participatory, collaborative, and circular research aimed at improving systems, methods, tasks, processes, content, skills, and status [8]. This circular shape aims to find flaws and correct them in the next cycle (Dwitagama, et. Al, 2011).

\section{A. Plan}

At this stage the authors plan all activities that will be carried out to make the application begins collecting data needed by first collecting data from library studies and secondly conducting interviews with financial staff at Muhammadiyah 3 junior high school then making an analysis of what is needed to fix the problem then create an application that will be applied to solve the problem.

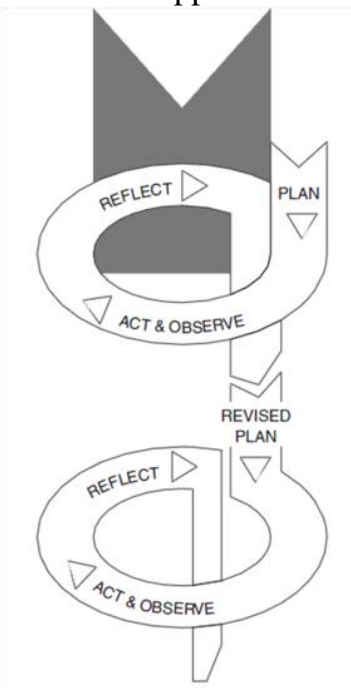

Picture 1. Cycle in Action Research

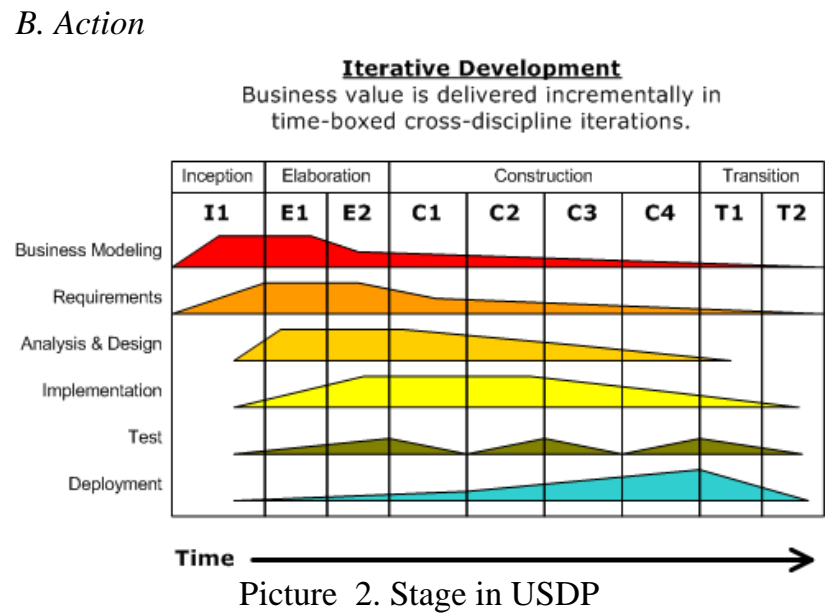

The authors designed an application using the USDP (Unified Software Development Process) method where the author chose USDP because of the use case driven USDP [10] where starting from the analysis, design and implementation rests on use case as a reference for making applications.in the USDP there are 6 stages that must be implemented namely (Nugroho, 2010):

1) Business Modeling

At this stage the author first collects data and analyses needs in the junior high school Muhammadiyah 3 dealing with Accounting. From the results of the analysis note that the staff is still working manually writing financial statements so that the work of the financial staff is still ineffective and inefficient. After the analysis process was carried out by interviewing staff from Muhammadiyah 3 junior high schools the authors concluded that it was necessary to create a software system that could make staff from finance work more effectively and efficiently.

\section{2) Requirement}

At this stage the author first collects data and analyses needs in the junior high school Muhammadiyah 3 dealing with Accounting. From the results of the analysis note that the staff is still working manually writing financial statements so that the work of the financial staff is still ineffective and inefficient. After the analysis process was carried out by interviewing staff from Muhammadiyah 3 junior high schools the authors concluded that it was necessary to make a software system that could make staff from finance work more effectively and efficiently.

3) Analisis dan Design

Based on the process of analysis and preparation of system requirements, then at this stage the authors design software that will be developed. The design process includes:

a. Develop modeling classes contained in the system to be developed.

b. Use Case Diagram Modeling.

c. Scenario Diagram Modeling.

d. Activity Diagram Modeling.

e. Sequence Diagram Modeling.

f. Making a sketch of the interface of each software page that will be developed. 


\section{4) Implementation}

After the analysis and design process is done, the writer then enters into the implementation phase. The process carried out at this stage is:

a. Creation of structures in database tables.

b. Creation of features that fit the purpose of software development.

c. Development of software in accordance with the modeling diagram and sketch of the interface that has been designed previously.

\section{5) Test}

At this stage the application that has been made will be tested to see the results of the application made. At this stage the author uses the black box testing method to test the application.

\section{6) Deployment}

At this stage, carried out:

a. Installing supporting software so that the software developed can run smoothly.

b. Configure the software so it can be used by the user.

c. Input data to a database that has been built so that it can be used by software.

\section{Observe}

If the application is as you wish then make observations to the application applied by looking directly at whether the application is running well.

\section{Reflect}

The author analyzes the results of the application of financial applications in Muhammadiyah 3 junior high school and reflects on what actions will be taken.

\section{RESULTS AND DISCUSSION}

1. Implementation of Login Interface

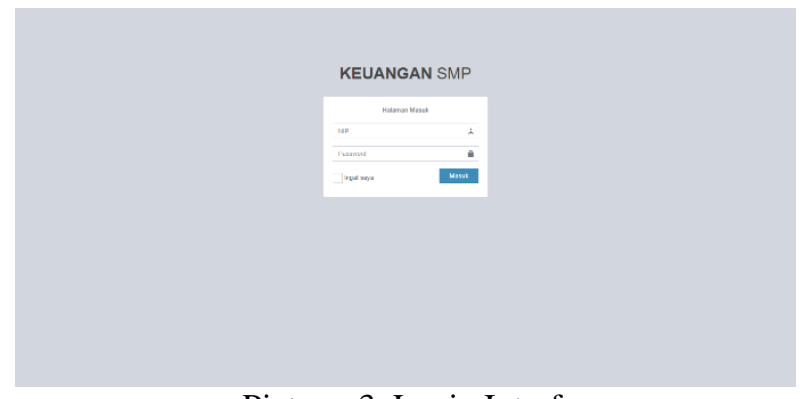

Picture 3. Login Interface

The picture above is a display of the application for the login page.
2. Implementation of the Report Interface

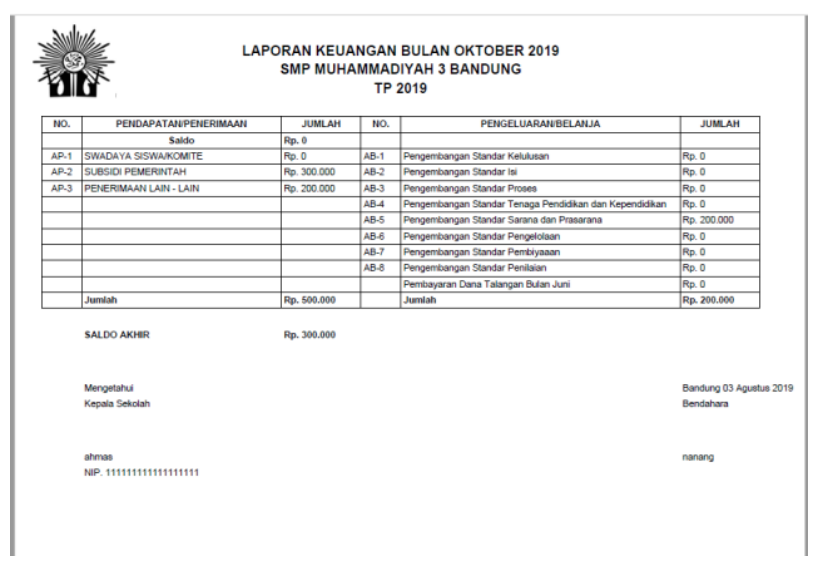

Picture 4. Reports Interface

The picture above is a display of the application for the report page.

\section{Testing system}

Here is the result of testing system using black box:

Table 1. Testing System using Black box

\begin{tabular}{|c|l|c|c|}
\hline No & \multicolumn{1}{|c|}{ Testing Items } & Sub Items & Result \\
\hline 1 & Login & Input validation & Success \\
\hline 2 & Employee & Input validation & Success \\
\hline & & Suitability of the process & Success \\
\hline 3 & Student & Input validation & Success \\
\hline 4 & Student Finance & Input validation & Success \\
\hline & & Suitability of the process & Success \\
\hline 5 & Income & Input validation & Success \\
\hline & & Suitability of the process & Success \\
\hline 6 & Report & Input validation & Success \\
\hline & & Suitability of the process & Success \\
\hline
\end{tabular}

\section{CONCLUSION}

The system that was built can reduce the use of paper/book reports during the recording process so that it is more effective and more efficient report processing because the processing of reports is easier and faster. With a web-based accounting application that is made can store student financial data more organized and when searching can be faster so that service to parents of students can be better. 